\title{
$\mathrm{J}$

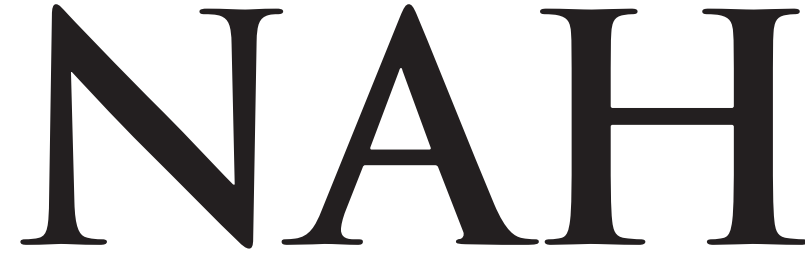 \\ THE JOURNAL OF NORTH AMERICAN HERPETOLOGY
}

Volume 2015(1): 53-59

2 May 2015

jnah.cnah.org

\section{SOUTHERNMOST OCCURRENCE OF THE SUWANNEE COOTER, PSEUDEMYS CONCINNA SUWANNIENSIS (TESTUDINES: EMYDIDAE)}

\author{
GEORGE L. HEI NRICH $\mathrm{CH}^{1,2}$, DALE R. JACKSON ${ }^{3}$, \\ TIMOTHY J. WALSH ${ }^{2,4}$, AND DAVID S. LEE ${ }^{*}$ \\ ${ }^{1}$ Heinrich Ecological Services, 1213 Alhambra Way S., St. Petersburg, Florida \\ 33705-4620, USA, george@heinrichecologicalservices.com (corresponding au- \\ thor) \\ ${ }^{2}$ Florida Turtle Conservation Trust, 1213 Alhambra Way S., St. Petersburg, Florida \\ 33705-4620, USA \\ ${ }^{3}$ Florida Natural Areas Inventory, Florida State University, 1018 Thomasville Road, \\ Suite 200-C, Tallahassee, Florida 32303, USA \\ ${ }^{4}$ Bruce Museum, 1 Museum Drive, Greenwich, Connecticut 06830-7157, USA \\ ${ }^{5}$ The Tortoise Reserve, P.O. Box 7082, White Lake, North Carolina 28337, USA \\ * deceased
}

\begin{abstract}
The Suwannee Cooter, Pseudemys concinna suwanniensis, the largest member of the speciose turtle family Emydidae, inhabits a small number of rivers that drain into the northeastern Gulf of Mexico along the northwest coast of Florida from just west of Tallahassee to just south of Tampa. The status of this state-protected subspecies in the southernmost of these rivers, the Alafia, is unknown and hence of conservation concern. We provide recent evidence confirming that a reproducing population still exists in this river, and review available specimens and both published and unpublished records documenting the southern limit of distribution. At least within the eastern United States, our observations also extend confirmed knowledge of the geographic occurrence of hatchling turtles overwintering in the nest southward by $285 \mathrm{~km}$.
\end{abstract}

\section{INTRODUCTION}

The Suwannee Cooter, Pseudemys concinna suwanniensis, is a large, herbivorous emydid turtle whose native range in Florida is restricted to river systems draining into the northeastern Gulf of Mexico, from the Ochlockonee River in the panhandle southward to the Tampa Bay region (Jackson 2006; Figure 1). Initially described as part of the Pseudemys floridana species complex (Carr 1937), subsequent investigations (Seidel 1981, 1994; Ward 1984; Jackson 1995) have placed suwanniensis within various taxonomies, including elevation to a full species. Currently, most authorities recognize suwanniensis as a subspecies of P. concinna (Jackson 1995, 2002, 2006; Seidel and Dreslik 1996; Meylan 2006). We follow the taxonomy used by Meylan (2006) and the Turtle Taxonomy Working Group (2014). This subspecies, of the more widely ranging River Cooter, is the largest emydid turtle in North America and exhibits pronounced sexual size dimorphism, with adult females reaching a maximum shell length of 43.7 cm (Pritchard 1980, Heinrich et al. 2010) and body mass $>10 \mathrm{~kg}$ (Jackson and Walker 1997). Males may reach a maximum shell length of at least $33.0 \mathrm{~cm}$ and a mass of $3.4 \mathrm{~kg}$ (Jackson 2006). Although the State of Florida currently lists the Suwannee Cooter as a Species of Special Concern, state authorities are in the process of rescinding this status but will continue to monitor and manage the taxon and protect it from human take (Florida Fish and Wildlife Conservation Commission 2013). Principal threats of concern thus far identified are take for human consumption (now illegal under Florida Administrative Code 68A-27.005), predation of turtles and nests, loss or degradation of nesting sites, riverine habitat degradation, and boat strikes (Jackson 2006; Heinrich et al. 2010, 2012).

The southern extent of the range of the Suwannee Cooter has been considered problematic for decades. Carr (1940, 1952) and Carr and Goin (1959), using the combination P. floridana suwanniensis, repeatedly listed Pinellas County (on the western side of Tampa Bay) as the southern extent, but that county lacks rivers of sufficient size to support this species and we know of 
no museum records for that county. Crenshaw (1955) provided the earliest reference to the occurrence of the Suwannee Cooter in the Alafia River (southeastern Hillsborough County, on the eastern [inland] side of the bay). Auffenberg (1978) and Jackson (1992) also reported that the range extends to the Alafia River, but provided no supporting data. Nearly all subsequent field guides and species accounts (reviewed by Jackson 2006) have included this river in the distribution, but without additional documentation. The subspecies' apparent absence from the Hillsborough River (Marchand 1942, Jackson 2006), a moderately large and seemingly suitable river north of the Alafia, leaves a substantial hiatus $(\sim 79 \mathrm{~km}$ between the Weeki Wachee and Alafia rivers) in the reported range and calls into question the validity of the Alafia River occurrence. Furthermore, two other large Pseudemys - the Peninsula Cooter, P. floridana peninsularis, and Florida Red-bellied Cooter, P. nelsoni, - inhabit freshwater bodies throughout the Florida peninsula, and the general similarities of the three species (compared in Meylan 2006) invite the possibility of misidentifications. Although the latter two species are predominantly lentic, both occur in some low-gradient rivers (e.g., Hillsborough River), and all three Pseudemys coexist in the Withlacoochee River. Since Auffenberg first drafted his account in the 1970s, nearly four decades have passed; during this period, the Alafia River basin has been degraded by mining, residential and recreational development, and other forms of habitat disturbance that are likely to have had negative effects on the river's biota. Thus, the status of P. C. suwanniensis in the Alafia River is ripe for review.

Our purpose in this report is two-fold. First, we provide new evidence confirming the existence of an extant, reproducing population of the Suwannee Cooter in the Alafia River and offer morphometric data for the southernmost hatchlings ever recorded for the species. Second, we consolidate and evaluate pre-existing evidence for the occurrence and status of this species in this river. These data are directly relevant not only to improving zoogeographic knowledge about the Suwannee Cooter, but also to conserving the gene pool of what may be an important peripheral population.

\section{STUDY AREA AND METHODS}

The Alafia River has a drainage of $\sim 1,082 \mathrm{~km}^{2}$ (Stoker et al. 1996), mostly in eastern Hillsborough County, with headwaters stemming from Polk County within one of the world's most important (and highly degraded) phosphate mining regions (Cardinale 1998). Two tributaries,

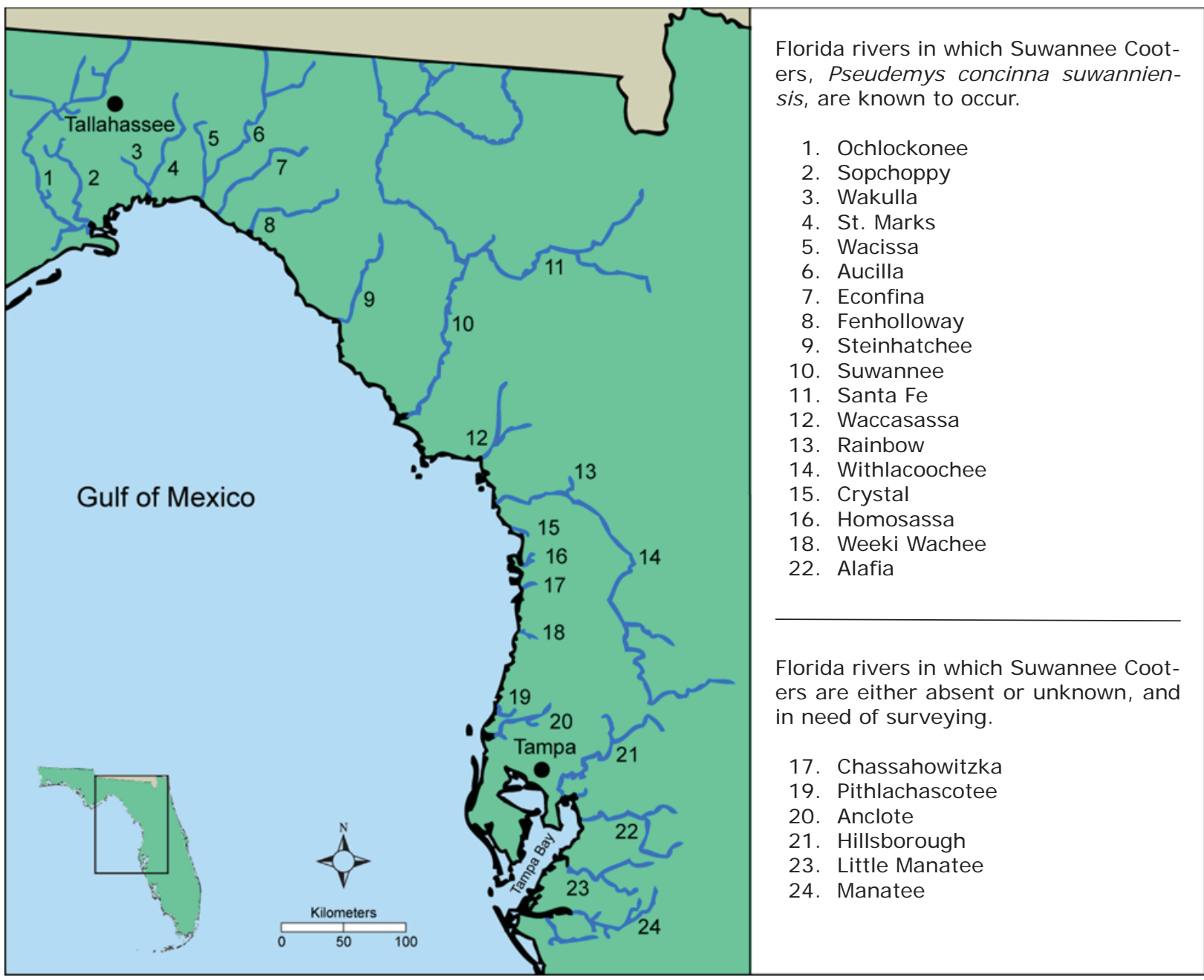

Figure 1. Map of Florida rivers in which Suwannee Cooters, Pseudemys concinna suwanniensis, occur (although apparently extirpated from the Fenholloway), as well as those rivers from which they are absent or unknown (Jackson 2006, Florida Fish and Wildlife Conservation Commission 2013). Presumably introduced populations (e.g., Silver River, St. Johns River system) are omitted. 
the North Prong Alafia River and South Prong Alafia River, flow westward from Polk County and merge at Alderman's Ford Regional Park located in eastern Hillsborough County. From that point, the Alafia River flows $\sim 37 \mathrm{~km}$ westward (Parsons 2008) and drains into Hillsborough Bay (northeastern arm of Tampa Bay) at Gibsonton. Two second magnitude springs - Buckhorn Main Spring and Lithia Spring Major - empty via short spring runs into the normally tannic river (Scott et al. 2004). The lower $\sim 18 \mathrm{~km}$ of the river are tidally influenced with a shoreline that is heavily developed with private homes (Cardinale 1998).

The report to one of the authors (GLH) of a successful turtle nest along the lower Alafia River confirmed that $P$. c. suwanniensis is still reproducing in this river. On $5 \mathrm{~J}$ anuary 2014, 17 Suwannee Cooter hatchlings were found in their nest (out of their eggs) by a resident digging in a flower bed at 11214 DeSoto Road, Riverview, Hillsborough County, Florida (N 27.87705, W -82.31311), on the northern bank of the river (Figures $2-3$ ). The immediate nest area was thoroughly searched at the time of discovery by the resident, who placed the hatchlings in a plastic bin containing wet soil. The resident then contacted Defenders of Wildlife who in turn requested assistance from GLH regarding species identification. Examination of digital photographs provided by the resident allowed identification based on plastral pattern. On 7 January 2014, GLH recorded maximum carapace length $(C L)$, maximum plastron length $(\mathrm{PL})$, maximum carapace width $(\mathrm{CW})$, and maximum shell height $(\mathrm{SH})$ to the nearest $1.0 \mathrm{~mm}$, mass to the nearest 0.1 gram, and distance from the nest to the river's edge. Since Florida wildlife regulations prohibit possession of Pseudemys without a permit, we photographed all individuals before their release by the resident. Digital photographs of the carapace and plastron of each specimen were deposited as vouchers at the Florida Museum of Natural History (UF 172509-172525; Figure 4). We examined the photographs to determine the degree of closure of the umbilical scars and presence/absence of caruncles.

The discovery of the above nest encouraged us to conduct a thorough review of all pre-existing evidence for the occurrence and status of the Suwannee Cooter in this river system. We conducted a search of U.S. museums, reviewed scientific and gray literature, and pursued records from workers familiar with the geographic area or species.

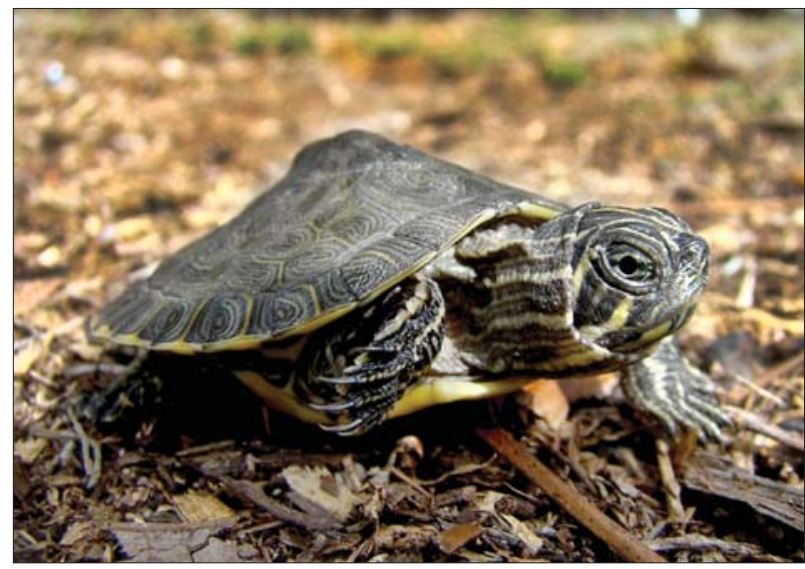

Figure 2. Hatchling Pseudemys concinna suwanniensis observed at Riverview, Hillsborough County, Florida by George L. Heinrich on 7 J anuary 2014. Photograph by George L. Heinrich.
We reviewed a March 1999 letter to Dale R. Jackson/Florida Natural Areas I nventory (file name: U99LEE01FLUS), in which David S. Lee summarized his observations and collections of Suwannee Cooters at Lithia Springs ( N 27.86632, W -82.23119) on the Alafia River from 19641968. In that letter, Lee reported that he removed $\sim 20$ turtles and that all but one specimen were placed in the biology building at Florida Southern College (Lakeland). He retained the shell of an adult female in his personal collection. Four juvenile specimens were later transferred back to Lee. Gabriel J. Langford (Florida Southern College) conducted a search in February 2014 for the remaining specimens at the college on our behalf. We recorded CL, PL, CW, and SH to the nearest $1.0 \mathrm{~mm}$, and digitally photographed the carapaces and plastra of the five specimens in Lee's possession. These five specimens were then deposited at the Florida Museum of Natural History (UF 173336-173340).

We also reviewed a 2003 compilation of Florida turtle specimens in U.S. museums prepared by John Iverson et al. (in litt.) in which four specimens (USNM 137634, 137635, 165916, and Crenshaw 1053) were identified as Suwannee Cooters collected from Lithia Springs on the Alafia River. We examined the three USNM specimens to verify identification and recorded $\mathrm{CL}, \mathrm{PL}, \mathrm{CW}$, and $\mathrm{SH}$ to the nearest $1.0 \mathrm{~mm}$, and sex when possible. Digital photographs were taken of the carapace and plastron of each specimen. We were unable to locate the specimen listed as Crenshaw 1053.

We conducted a search of 42 natural history museum collections with databases accessible through VertNet. org (beta) and HerpNet.org (on 12 February 2014) to identify additional specimens of $P$. C. suwanniensis from Hillsborough and Pinellas counties. Three other collection databases were accessed through their institutional websites. Pinellas County was included because of Carr's (1940, 1952) and Carr and Goin's (1959) reports of P. c. suwanniensis (then $P$. floridana suwanniensis) from that county. We searched for specimens collected from 1937 to present to avoid taxonomic confusion and species misidentification; our database searches would not necessarily have identified specimens deposited prior to Carr's (1937) description of the subspecies. We also contacted the senior author of the Atlas of Amphibians and Reptiles in Florida (Krysko et al. 2011) to determine the basis of a record(s) mapped in Hillsborough County.

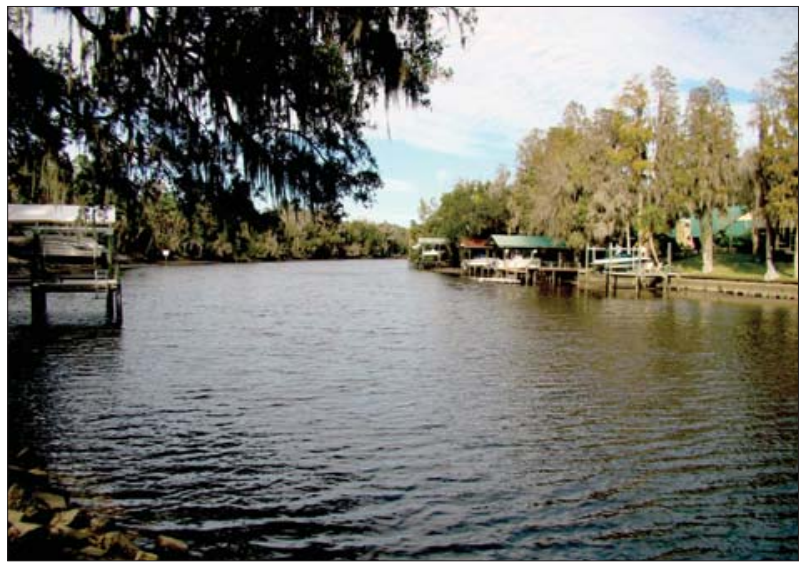

Figure 3. View of Alafia River from Pseudemys concinna suwanniensis nesting site, Riverview, Hillsborough County, Florida on 7 January 2014. Photograph by George L. Heinrich. 
Table 1. Publications, reports, and specimens documenting the occurrence of Pseudemys concinna suwanniensis in the Alafia River (Hillsborough County, Florida) from 1953-2014.

\begin{tabular}{ll}
\hline Source & Description \\
\hline Crenshaw (1955) & unpublished Ph.D. dissertation \\
David S. Lee & $\sim 20$ specimens placed at Florida Southern College ca. 1965 (no catalog numbers provided); \\
& four juveniles later transferred back to Lee with the remainder reported to have been lost; these \\
& four plus an additional adult shell (collected in 1966) were deposited at the FLMNH in 2014 (UF \\
& $173336-173340)$
\end{tabular}

Lee (1969)

Kenneth L. Krysko and Henry

R. Mushinsky (personal

communication)

Peter A. Meylan (personal communication)

David S. Lee

John B. I verson et al.

George L. Heinrich

\section{published note}

hatchling specimen collected in 1975 and placed at University of South Florida (no catalog number provided) - reported to have been destroyed

capture of a basking juvenile ca. 1989

letter dated March 1999 to Florida Natural Areas Inventory summarizing observations and collections from 1964-1968

2003 compilation of Florida turtle specimens in U.S. museums - includes two juvenile specimens collected by Auffenberg, Ogren, and Crenshaw in 1953 (USNM 137634, USNM 137635), an immature specimen collected by Lee in 1968 (USNM 165916), and a fourth specimen (Crenshaw 1053) for which the collection date and current location were undetermined

17 hatchlings observed in 2014 and reported in this study (digital photographs deposited as vouchers; UF 172509-172525)

\section{RESULTS}

Mean measurements of the 17 P. c. suwanniensis hatchlings collected from the nest at the Riverview site were CL $41.3 \mathrm{~mm}$ (range: $40-43 \mathrm{~mm}$ ), PL $37.9 \mathrm{~mm}$ (37-40 mm), CW $41.0 \mathrm{~mm}(39-43 \mathrm{~mm}), \mathrm{SH} 19.8 \mathrm{~mm}$ (18-21 mm), and mass 12.3 grams (11.3-14.7 g). Umbilical scars were closed, and caruncles absent on all specimens, indicating that at least 6 weeks (likely more) had passed since hatching. These are the first hatchling morphometric data collected for this subspecies from the Alafia River. The nest was $31.4 \mathrm{~m}$ from the edge of the river.

We identified seven primary sources of information (publications, reports, and records of $\sim 26$ specimens) that documented this species' occurrence in the Alafia River from 1953-1989 (Table 1). Several secondary listings of this occurrence (e.g., Auffenberg [1978], Jackson [1992], and Hipes et al. [2001]) offered no additional data. Our search efforts revealed that only eight of the recorded specimens still exist, making the 17 P. c. suwanniensis hatchlings documented in 2014 at the Riverview site in Hillsborough County a valuable addition to the museum record for this subspecies.

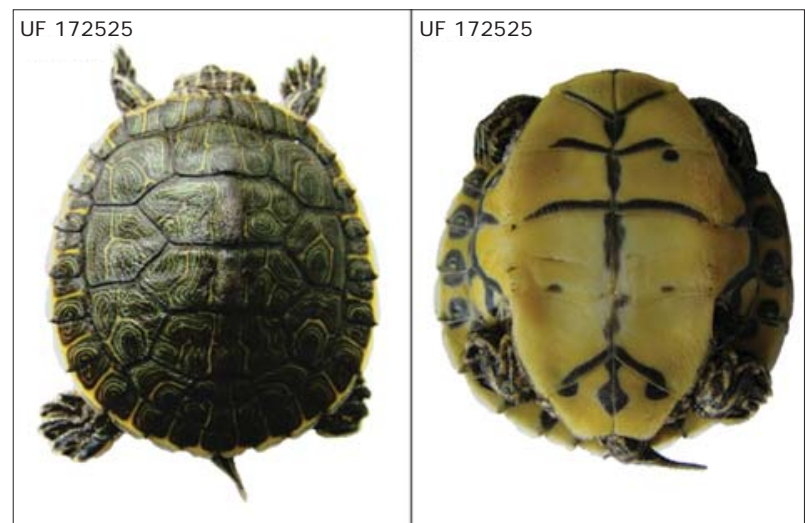

Figure 4. Hatchling Pseudemys concinna suwanniensis ( $C L 40$ mm, PL 38 $\mathrm{mm}$ ) observed at Riverview, Hillsborough County, Florida by George L. Heinrich on 7 January 2014 (photographic voucher: UF 172525). Photographs by George L. Heinrich.
Regrettably, the majority of the specimens collected by Lee at Lithia Springs and placed at Florida Southern College ca. 1965 could not be located (Gabriel J. Langford, personal communication, 7 February 2014), and it is likely that they no longer exist. The single shell (now UF 173336) collected from the same location on 17 June 1966 is an adult female with the following measurements: CL 402 mm, PL 361 mm, CW 293 mm, SH $162 \mathrm{~mm}$; Figure 5); Lee recorded that it contained 20 shelled eggs. The four juvenile specimens that were transferred back to Lee had the following measurements (UF 173337: CL 116 mm, PL 105 mm, CW 95 mm, SH 45 mm; UF 173338: CL $118 \mathrm{~mm}, \mathrm{PL} 108 \mathrm{~mm}, \mathrm{CW} 96 \mathrm{~mm}$, SH $48 \mathrm{~mm}$; UF 173339: CL $123 \mathrm{~mm}, \mathrm{PL} 111 \mathrm{~mm}, \mathrm{CW}$ $101 \mathrm{~mm}, \mathrm{SH} 51 \mathrm{~mm}$; and UF 173340: CL $123 \mathrm{~mm}, \mathrm{PL}$ $114 \mathrm{~mm}, \mathrm{CW} 101 \mathrm{~mm}, \mathrm{SH} 50 \mathrm{~mm}$ ). All were too young to determine sex based on sexually dimorphic characters (foreclaw and pre-cloacal tail lengths).

The three specimens of P. c. suwanniensis in the collection of the National Museum of Natural History are all juveniles collected from Lithia Springs on the Alafia River. Two of these were collected by Walter Auffenberg, Larry H. Ogren, and J ohn W. Crenshaw, J r. on 22 Novem-

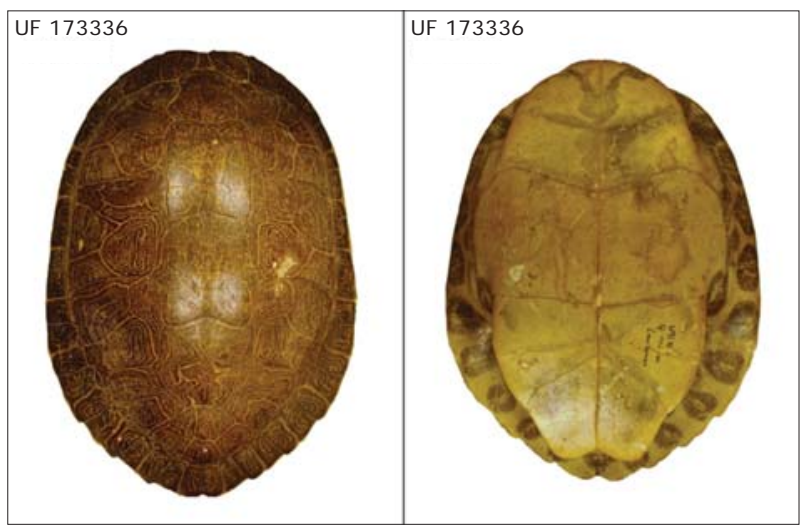

Figure 5. Shell of adult female Pseudemys concinna suwanniensis (CL 402 $\mathrm{mm}, \mathrm{PL} 361 \mathrm{~mm}$ ) collected at Lithia Springs, Hillsborough County, Florida by David S. Lee on 17 June 1966 (UF 173336). Photographs by George L. Heinrich. 
ber 1953 (USNM 137634: CL 86 mm, PL 75 mm, CW 72 $\mathrm{mm}, \mathrm{SH} 40 \mathrm{~mm}$, sex undetermined; and USNM 137635: CL $78 \mathrm{~mm}$, PL $70 \mathrm{~mm}$, CW $68 \mathrm{~mm}$, SH $38 \mathrm{~mm}$, sex undetermined; Figure 6). A third immature specimen was collected by David S. Lee in July 1968 (USNM 165916: CL 167 mm, PL 152 mm, CW 133 mm, SH 59 mm, probable male).

Our search of 45 natural history museum collections yielded no further specimens of P. C. suwanniensis from either Hillsborough or Pinellas counties. The locality reference for Hillsborough County in the Atlas of Amphibians and Reptiles in Florida (Krysko et al. 2011) represents 4 specimens (Kenneth L. Krysko, personal communication). Three records are for the USNM specimens listed above. A fourth specimen (no catalog number available) was in the collection of the University of South Florida; however that specimen was apparently destroyed during renovation of the science building (Henry R. Mushinsky, personal communication). Krysko reported that it was a single hatchling collected in 1975 from the Alafia River between Hwy 640 and Lithia Springs.

One additional capture of a basking juvenile Suwannee Cooter was made by Peter A. Meylan (personal communication) ca. 1989 on the Alafia River between Lithia Springs and Bell Shoals Road. Table 1 summarizes data for all Alafia River specimens known to us.

Lee's specimens and observations from the mid-1960s provide the only ecological and behavioral data for P. C. suwanniensis in the Alafia River. The species apparently was common at least in the vicinity of Lithia Springs at that time. Lee estimated that as many as 50-75 adult and subadult Suwannee Cooters (including 30 that he marked) foraged in the main spring and its short run early each morning, although they typically moved back into the river as people arrived for recreation; some juveniles were also present. His field observations and stomach analyses of at least 10 individuals revealed the predominant dietary item to be the invasive aquatic plant Brazilian elodea, Egeria densa, which filled approximately $50-60 \%$ of the spring run; unidentified green alga(e) that was restricted to the spring head constituted a secondary food item. Suwannee Cooters did not use a much smaller, elodea-free spring run just downstream. Within a span of less than one year, as the land manager eliminated aquatic plants (reportedly with herbicides) from the main spring and run, cooters abandoned use of the site.

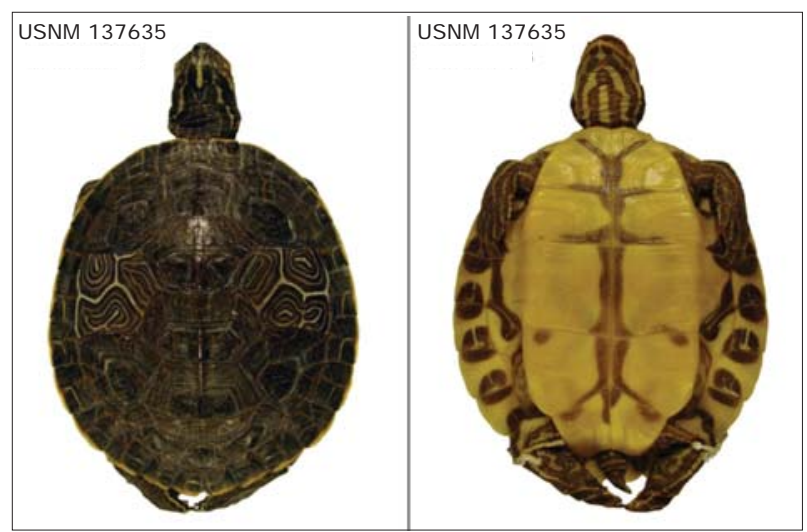

Figure 6. Juvenile Pseudemys concinna suwanniensis (CL $78 \mathrm{~mm}, \mathrm{PL} 70$ $\mathrm{mm}$ ) collected from Lithia Springs, Hillsborough County, Florida by Walter Auffenberg, Larry H. Ogren, and John W. Crenshaw on 22 November 1953 (USNM 137635). Photographs by George L. Heinrich.

\section{DISCUSSION}

This paper summarizes evidence for the occurrence and status of the Suwannee Cooter in the Alafia River through January 2014. About 26 specimens are known to have been collected from this drainage and deposited in either natural history museum collections or college/ university biology departments from 1953-1975. We were able to confirm continued existence of only eight of those specimens. The loss or destruction of the majority of the turtles underscores the importance of depositing specimens into permanent and properly curated collections. We found no evidence to substantiate reports of the Suwannee Cooter from Pinellas County (Carr 1940, 1952; Carr and Goin 1959) and conclude that these are erroneous.

Evidence of this species in the Alafia River is sparse during the 61-year span between collection of the first two specimens by Auffenberg, Ogren, and Crenshaw in 1953 and the 2014 nest observation we describe (Table 1). Other than secondary reports, we identified only Crenshaw's unpublished Ph.D. dissertation (1955), Lee's 1964-1968 field observations and specimens (also noted in Lee 1969 and Lee's 1999 letter), a lost USF specimen (1975), a juvenile captured by Meylan (ca. 1989), and a 2003 compilation of Florida turtle specimens in U.S. museums prepared by Iverson et al. After a hiatus of at least a quarter century, the discovery of the 17 hatchlings in 2014 documents the continued existence of a reproducing population in the southernmost river from which this typically conspicuous turtle is known.

Clutch size of the Alafia River nest corresponds closely with previously documented clutch sizes from other sites. Jackson and Walker (1997) reported a mean of 17.5 (range: 8-27, $\mathrm{N}=88$ ) for the Wakulla River (Wakulla County) population in northwestern Florida. Jackson and Jackson (1968) reported a mean of 17.7 (range: 17- $19, \mathrm{~N}=3$ ) from Marion and adjacent counties in the north-central peninsula. Unpublished data from the Santa Fe River (Alachua County) in the northern peninsula (mean 19.0, range: 18-20, $\mathrm{N}=2$; Jerry Johnston, personal communication) and Rainbow River (Marion County) (mean 20.0, range: 17-24, $N=7$; Peter A. Meylan, personal communication) are similar.

Laboratory-incubated hatchlings from eggs collected along the Wakulla River had a mean $\mathrm{CL}$ of $38.1 \mathrm{~mm}$ (range: $32.3-43.2 \mathrm{~mm}, \mathrm{~N}=225)$, $\mathrm{PL}$ of $34.2 \mathrm{~mm}(29.0$ $38.7 \mathrm{~mm}, \mathrm{~N}=225), \mathrm{CW}$ of $37.3 \mathrm{~mm}(29.2-43.6 \mathrm{~mm}$, $\mathrm{N}=222)$, and mass of 11.4 grams $(6.8-14.6 \mathrm{~g}, \mathrm{~N}=179)$ (Jackson and Walker 1997). Jackson and Jackson (1968) reported a mean $\mathrm{CL}$ of $36.7 \mathrm{~mm}$ (range: $32.7-38.9 \mathrm{~mm}$, $\mathrm{N}=54)$, PL of $32.9 \mathrm{~mm}(29.2-35.3 \mathrm{~mm}, \mathrm{~N}=54), \mathrm{CW}$ of $33.8 \mathrm{~mm}(26.3-38.0 \mathrm{~mm}, \mathrm{~N}=54)$, and mass of 12.4 grams (10.4-13.8 g, $\mathrm{N}=30$ ) for one-week old laboratory-incubated hatchlings from eggs from Marion and adjacent counties. Although the Alafia River hatchlings had greater mean linear measurements, this difference could be attributable to the length of time since hatching or to the limited sample size of one clutch.

Besides its zoogeographic and conservation importance, our study supplements knowledge about the geographic extent of the phenomenon of hatchling overwintering (delayed emergence) in turtles (Gibbons and Nelson 1978, Jackson 1994). The nesting season of the Suwannee Cooter is from late March to early August (Jackson and Walker 1997). In northern (panhandle) Florida, some clutches of hatchlings emerge from nests in the fall, within 100-157 days of oviposition, whereas others overwinter in the nest until the following spring, 
240-318 days post-nesting (Jackson 1994). The excavation of a clutch of hatchlings in January along the Alafia River extends the confirmed geographic extent of hatchling overwintering not only for the Suwannee Cooter, but for any eastern U.S. turtle species southward by 285 $\mathrm{km}$ (straight-line north-south) to central peninsular Florida. This observation provides further evidence that the phenomenon of hatchling overwintering may not have evolved strictly as an adaptation to avoid cold northern hemisphere temperature regimes.

Accurate delineation of the Suwannee Cooter's distribution is vital to assuring appropriate conservation and management efforts. The limited references to this species in the Alafia River illustrate the paucity of fieldwork conducted to date. Surveys are needed to determine its distribution and relative abundance within this river system (Auffenberg 1978, Jackson 1992). Furthermore, no systematic surveys for $P$. c. suwanniensis have been conducted on rivers north of the Alafia River and south of the Weeki Wachee River ( $\sim 79 \mathrm{~km}$ distance), where the species is next known to occur. Rivers within this span should be surveyed, as should the Little Manatee and Manatee rivers that respectively lie $\sim 17 \mathrm{~km}$ and $\sim 44$ $\mathrm{km}$ south of the Alafia River. If systematic surveys of the southern range of $\mathrm{P}$. c. suwanniensis prove the Alafia River population to be disjunct, genetic studies would certainly be warranted. Interestingly, Lee only observed adult Suwannee Cooters with bold carapacial patterns more similar to patterns of other subspecies, as well as of juveniles, rather than the dark carapaces that normally characterize adults elsewhere within the subspecies' range.

In his letter to the Florida Natural Areas Inventory (1999), Lee reported that the Lithia Springs population of Suwannee Cooters declined from 1964-1968 as the habitat was severely modified to support increased human recreation. As mentioned earlier, the Alafia River basin has a long history of anthropogenic disturbance. Of particular significance is a major spill event that occurred on 7 December 1997 when a breach of a containment facility at Mulberry Phosphates Inc. (Mulberry, Polk County) resulted in approximately 50 million gallons of acidic process water flowing into the North Prong of the river. The drastic lowering of $\mathrm{pH}$ caused lethal conditions for flora and fauna (including alligators) at the point of entry and downstream for the length of the river (Cardinale 1998). Presumably, a relict population of Suwannee Cooters survived, either in the South Prong, adjacent springs and tributaries, or beyond the river's mouth. Nonetheless, it remains critical to monitor this ecosystem carefully for existing and potential threats to both aquatic habitat and adjacent upland nesting areas of P. C. suwanniensis to assure that appropriate conservation and management activities are in place to protect this important population.

\section{ACKNOWLEDGEMENTS}

We thank Benjamin K. Atkinson (University of Florida), Greg Colgan (Eckerd College), Charles Lee (Audubon Florida), and Ann Paul (Audubon Florida) for assistance with locating publications. Our search for Alafia River voucher specimens was aided by an earlier list of Florida turtles in natural history collections compiled by John B. Iverson (Earlham College, retired). Kenneth L. Krysko (Florida Museum of Natural History), Gabriel J. Langford (Florida Southern College), Peter A. Meylan (Eckerd College), Henry R. Mushinsky (University of South Florida), and Larry H. Ogren (National Marine Fisheries Service, retired) assisted our search for specimens. We thank Robert Wilson and Kevin de Queiroz (Smithsonian Institution National Museum of Natural History) for lending us the three USNM specimens, and Peter A. Meylan for facilitating the loan. Jerry Johnston (Santa Fe College) and Peter A. Meylan kindly shared unpublished data. We are most grateful to Defenders of Wildlife and Nicole Melnick for reporting the discovery of the 17 hatchlings found in Riverview and for the latter allowing us to work at her home. Kenneth L. Krysko assisted us with submission of digital photographs that were deposited as vouchers and provided catalog numbers. We thank David J. DeWitt (Southwest Florida Water Management District) for providing a base map used to produce our map of Florida rivers. Thoughtful review by Brian D. Horne (Wildlife Conservation Society), Peter A. Meylan, and two anonymous reviewers significantly improved an earlier draft of this manuscript.

\section{LITERATURE CITED}

Auffenberg, W. 1978. Threatened: Suwannee cooter, Chrysemys concinna suwanniensis (Carr). Pp. 32-33 In R.W. McDiarmid (Ed.), Amphibians and Reptiles, Rare and Endangered Biota of Florida, Vol. 3. University Presses of Florida, Gainesville.

Cardinale, T. 1998. Mulberry Phosphates Inc. - December 1997 acid spill: Water quality impacts on Alafia River and Tampa Bay. Water Management Division Report, Environmental Protection Commission of Hillsborough County, Florida. 79 pp.

Carr, A. 1952. Handbook of Turtles. Cornell University Press, Ithaca, New York. 542 pp.

Carr, A. and C.J. Goin. 1959. Guide to the Reptiles, Amphibians, and Fresh-water Fishes of Florida. University of Florida Press, Gainesville. 341 pp.

Carr, A.F., J r. 1937. A new turtle from Florida, with notes on Pseudemys floridana mobiliensis (Holbrook). Occasional Papers of the Museum of Zoology, University of Michigan 348: 1-7, 2 pls.

Carr, A.F., J r. 1940. A contribution to the herpetology of Florida. University of Florida Publication, Biological Science Series 3: 1-118.

Crenshaw, J.W., Jr. 1955. The ecological geography of the Pseudemys floridana complex in the southeastern United States. Ph.D. dissertation. University of Florida, Gainesville.

Florida Fish and Wildlife Conservation Commission. 2013. A species action plan for the Suwannee Cooter (Pseudemys concinna suwanniensis). Final draft. Tallahassee, Florida. 46 pp. Web. http://myfwc.com/ media/2738286/Suwannee-Cooter-Species-ActionPlan-Final-Draft. pdf. Accessed on 8 September 2014

Gibbons J.W. and D.H. Nelson. 1978. The evolutionary significance of delayed emergence from the nest by hatchling turtles. Evolution 32:297-303.

Heinrich, G.L., T.J. Walsh, D.R. Jackson, and B.K. Atkinson. 2012. Boat strikes: a threat to the Suwannee cooter (Pseudemys concinna suwanniensis). Herpetological Conservation and Biology 7: 349-357.

Heinrich, G.L., T.J. Walsh, N.M. Mattheus, J.A. Butler, and P.C.H. Pritchard. 2010. Discovery of a modern-day midden: continued exploitation of the Suwannee cooter, Pseudemys concinna suwanniensis, and implications for conservation. Florida Scientist 73: 1419.

Hipes, D., D.R. Jackson, K. NeSmith, D. Printiss, and K. Brandt. 2001. Field Guide to the Rare Animals of Florida. Florida Natural Areas Inventory, Tallahassee. 
Jackson, C.G., Jr. and M.M. Jackson. 1968. The egg and hatchling of the Suwannee terrapin. Quarterly J ournal of the Florida Academy of Sciences 31: 199-204.

Jackson, D.R. 1992. Species of Special Concern: River cooter, Pseudemys concinna (Le Conte). Pp. 166170 In P.E. Moler (Ed.), Amphibians and Reptiles, Rare and Endangered Biota of Florida, Vol. 3. University Press of Florida, Gainesville.

Jackson, D.R. 1994. Overwintering of hatchling turtles in northern Florida. Journal of Herpetology 28:401402.

Jackson, D.R. 1995. Systematics of the Pseudemys concinna-floridana complex (Testudines: Emydidae): an alternative interpretation. Chelonian Conservation and Biology 1:329-333.

Jackson, D.R. 2002. Survey of an important distributional gap in the Florida range of the river cooter and other freshwater turtles. Final Report. Florida Fish and Wildlife Conservation Commission, Tallahassee. $27 \mathrm{pp}$.

Jackson, D.R. 2006. Pseudemys concinna - River Cooter. Pp. 325-337 In P.A. Meylan (Ed.), Chelonian Research Monographs No. 3: Biology and Conservation of Florida Turtles. Chelonian Research Foundation, Lunenburg, Massachusetts.

Jackson, D.R. and R.N. Walker. 1997. Reproduction in the Suwannee cooter, Pseudemys concinna suwanniensis. Bulletin Florida Museum Natural History 41:69- 167.

Krysko, K.L., K.M. Enge, and P.E. Moler. 2011. Atlas of Amphibians and Reptiles in Florida. Final Report, Project Agreement 08013, Florida Fish and Wildlife Conservation Commission, Tallahassee. 524 pp. Web. http: // www. flmnh.ufl.edu/files/1513/9655/3772/ herps_atlas_low.pdf. Accessed on 8 September 2014.

Lee, D.S. 1969. The spring redeye chub in Lithia Springs. The Florida Naturalist 42(1): 39.

Marchand, L.J. 1942. A contribution to a knowledge of the natural history of certain freshwater turtles. Master's thesis. University of Florida, Gainesville.

Meylan, P.A. (Ed.). 2006. Biology and Conservation of Florida Turtles. Chelonian Research Monographs No. 3, Chelonian Research Foundation, Lunenburg, Massachusetts. $376 \mathrm{pp}$.

Parsons. 2008. Alderman's Ford Park land management and land use plan. Prepared for the Hillsborough County Parks, Recreation and Conservation Department, Tampa, Florida. 40 pp.

Pritchard, P.C.H. 1980. Record size turtles from Florida and South Amerika. Chelonologica 1(3): 113-123.

Scott, T.M., G.H. Means, R.P. Meegan, R.C. Means, S.B. Upchurch, R.E. Copeland, J. Jones, T. Roberts, and A. Willet. 2004. Springs of Florida. Florida Geological Survey Bulletin No. 66, Florida Department of Environmental Protection, Division of Resource Assessment and Management, Tallahassee. 377 pp.

Seidel, M.E. 1981. A taxonomic analysis of pseudemyd turtles (Testudines: Emydidae) from the New River, and phenetic relationships in the subgenus Pseudemys. Brimleyana 6:25-44.

Seidel, M.E. 1994. Morphometric analysis and taxonomy of cooter and red-bellied turtles in the North American genus Pseudemys (Emydidae). Chelonian Conservation and Biology 1:117-130.

Seidel, M.E. and M.J. Dreslik. 1996. Pseudemys concinna (LeConte), river cooter. Catalogue of American Amphibians and Reptiles 626.1-626.12. Society for the Study of Amphibians and Reptiles.

Stoker, Y.E., V.A. Levesque, and W.M. Woodham. 1996 The effect of discharge and water quality of the Alafia River, Hillsborough River, and the Tampa Bypass Canal on nutrient loading to Hillsborough Bay, Florida. U.S. Geological Survey, Water-Resources Investigations Report 95-4107, Tallahassee, Florida. 69 pp.

Turtle Taxonomy Working Group [van Dijk, P.P., J.B. I verson, A.G.J. Rhodin, H.B. Shaffer, and R. Bour]. 2014. Turtles of the world, $7^{\text {th }}$ edition: annotated checklist of taxonomy, synonymy, distribution with maps, and conservation status. In A.G.J. Rhodin, P.C.H. Pritchard, P.P. van Dijk, R.A. Saumure, K.A. Buhlmann, J.B. Iverson, and R.A. Mittermeier (Eds.), Conservation Biology of Freshwater Turtles and Tortoises: A Compilation Project of the IUCN/SSC Tortoise and Freshwater Turtle Specialist Group. CheIonian Research Monographs 5(7): 000.329-479, doi: 10.3854/crm.5.000. checklist.v7.2014. Chelonian Research Foundation, Lunenburg, Massachusetts.

Ward, J.P. 1984. Relationships of chrysemyd turtles of North America (Testudines: Emydidae). Special Publications, The Museum, Texas Tech University 21: 150 . 